\title{
Differences in Attitude to Corporate Social Responsibility among Generations
}

\author{
Jelena Titko $^{1}\left(\mathbb{D}\right.$, Anna Svirina ${ }^{1}$, Tatjana Tambovceva ${ }^{2}$ (D) and Viktorija Skvarciany ${ }^{3, *(D)}$ \\ 1 EKA University of Applied Sciences, LV-1019 Riga, Latvia; jelena.titko@eka.edu.lv (J.T.); \\ anna_svirina@list.ru (A.S.) \\ 2 Faculty of Engineering Economics and Management, Riga Technical University, LV-1048 Riga, Latvia; \\ tatjana.tambovceva@rtu.lv \\ 3 Faculty of Business Management, Vilnius Gediminas Technical University, LT-10223 Vilnius, Lithuania \\ * Correspondence: viktorija.skvarciany@vilniustech.lt
}

check for updates

Citation: Titko, J.; Svirina, A.; Tambovceva, T.; Skvarciany, V. Differences in Attitude to Corporate Social Responsibility among Generations. Sustainability 2021, 13, 10944. https://doi.org/10.3390/ su131910944

Academic Editor: Ioannis Nikolaou

Received: 26 August 2021

Accepted: 28 September 2021

Published: 1 October 2021

Publisher's Note: MDPI stays neutral with regard to jurisdictional claims in published maps and institutional affiliations.

Copyright: (c) 2021 by the authors. Licensee MDPI, Basel, Switzerland. This article is an open access article distributed under the terms and conditions of the Creative Commons Attribution (CC BY) license (https:/ / creativecommons.org/licenses/by/ $4.0 /)$.

\begin{abstract}
The purpose of the study is to investigate the employees' attitudes to CSR practices and reveal the differences in staff perceptions within different groups of responadents. The tasks to be accomplished are: (1) to investigate the differences of CSR perception between males and females; (2) to investigate the differences of CSR perception among representatives of different generations; (3) to investigate the differences of CSR perception among representatives of different sectors of the economy. The online survey was conducted using the authors' developed research instrument (questionnaire). In total, 129 respondents-employed Latvian citizens-participated in the survey. To assess the influence of age, gender, and other control characteristics in the sample, the authors implemented regression-based moderation analysis in the SPSS environment. The analysis indicated the moderating role of gender in the perception of corporate social responsibility, which appeared to be strong, especially in terms of leveraging business honesty, as a predictor. The sector, too, appeared to be a moderator, though it was much less statistically significant than gender. On the other hand, generation appeared to be an independent and significant predictor of corporate social responsibility perception itself, while its moderating effect was insignificant. The findings in the paper support existing literature in terms of moderating the role of gender, as outlined previously; yet, this research estimated that males value corporate social responsibility higher than females, while our results estimate the opposite. Our research revealed that age (generation) is a significant factor, which defines a personal attitude towards corporate social responsibility, i.e., the older generation values CSR higher than the youngsters. We have not found any correlation between the economic sector and corporate social responsibility perception.
\end{abstract}

Keywords: corporate social responsibility; perception; gender; generation; sector

\section{Introduction}

Sustainable development is one of the core concepts investigated by scholars from different scientific fields, as sustainable development goals are about to be reached by 2030. Hence, it is vital to investigate the drivers of sustainable development. There are scientists claiming that sustainability and CSR align with each other [1-3]. In other words, it could be stated that CSR is one of the factors contributing to sustainable development; hence, it is vital to investigate CSR in order to understand the attitude toward it, as the attitude could be treated as the key antecedent to reach a higher level of CSR and, therefore, sustainable development.

The number of scientific papers devoted to the issues related to socially responsible business, CSR, and business ethics has seen exponential growth during the last decades. The search using the keywords "corporate social responsibility," made in the SCOPUS database, has revealed more than 20,000 papers published from 2010-2021. 
The development of the concept of Corporate Social Responsibility (CSR) has more than 60 years of history. It was introduced in 1953 [4] and was then investigated by many researchers in different fields and concerning other concepts, such as company's performance [5], customer satisfaction and loyalty [6,7], corporate image [8], as well as employee satisfaction and loyalty [9]. Besides, the researchers pay attention to the questions, regarding the perception of CSR, by the company's employees, managers and top executives [10,11], ethical leadership [12], and the reputation of boards members [13].

The reason for the authors' intention to investigate the attitude towards CSR, depending on individual characteristics of surveyed employees, is the fact that the number of relevant studies in Latvia is quite small. The results of previously conducted researches revealed that perception of CSR, in terms of gender, should be examined on every market separately, as it could depend on historical and cultural variables of each particular country. Other studies yielded contradictory results, investigating differences in attitudes towards CSR depending on age. Besides, there is a small number of studies investigating the impact of the represented sector of employment on CSR perception. Thus, there is an obvious necessity to study the differences in attitudes towards CSR practices within the national context. The goal of the current paper is to investigate the employees' attitude to CSR practices and reveal the differences in staff perceptions within different groups of respondents. The research continues the previously conducted study [14]. The online survey was conducted using the authors' developed research instrument (questionnaire). In total, 129 respondents-employed Latvian citizens-participated in the survey.

To achieve the research goal and test the research hypotheses, the authors applied regression analysis to identify the moderating effects of the control features in the sample (gender, age, and sector of the economy).

The findings revealed that age and gender are significant factors that define personal attitude towards corporate social responsibility. In turn, the relationship between the economic sector and corporate social responsibility perception was not supported.

The paper contributes to the knowledge base in the field of CSR-related issues, identifying key determinants of employees' perception of CSR practices within the Latvian context. Other researchers studying the same topic could use the developed research instrument, making a test for internal consistency, based on their sample data.

The awareness about the differences in attitudes towards CSR, depending on personal characteristics, could help to re-examine the internal communication strategy focusing on different target groups.

\section{Determinants of Employees' Perception of Corporate Social Responsibility}

The list of benefits from a company's commitment to socially responsible principles of doing business is quite extensive and includes both financial and non-financial outcomes $[15,16]$. Many researchers point to the significant effect of CSR practices on employees' satisfaction and loyalty and, consequently, on reduced staff turnover and a better organisational commitment [17-19]. There is a wide range of studies supporting the hypothesis about the positive relationships between CSR orientation and business financial performance [20,21]. Many studies link CSR with customer satisfaction and, consequently, with improved business outcomes expressed in increased financial results or market value $[22,23]$.

The significant role of CSR in the pyramid of relationships within the organisation indicates the necessity for in-depth investigation of employees' attitudes towards CSR [24,25] and factors affecting staff perceptions. Some researchers focus on company-related factors affecting staff attitudes towards CSR, for instance, "organisational culture and climate, by whether CSR policies are couched in terms of compliance or terms of values, and by whether such policies are integrated into business processes" [26]. Another point in the focus of researchers is a relationship between CSR and employee-related outcomes, such as job satisfaction [27], or CSR and employees' behaviour, such as creativity, taking charge, and others $[28,29]$. 
The authors of the given paper focus on analysing such factors as respondents' gender, age, and sector of employment. Age groups were defined based on the concept of generations [30].

In general, the list of scientific papers devoted to the analysis of the impact of staff personal characteristics on attitude towards CSR is quite long. Most often, researchers pay their attention to studying the role of age, gender, and education [31-34].

The aspect of gender, in terms of CSR, is discussed in the scientific literature; however, the researches remain fragmented. For example, Rosati et al., (2018) conducted research on bank employees' approach to CSR and singled out that males are slightly more trusting in, and are satisfied with, CSR performance than females. In turn, García-Sánchez et al. [35] state that females present greater commitment to CSR than men. Nwude and Nwude [36] claim that feminine directors on the board could support a higher level of CSR. Despite various points of view, scientists agree that CSR plays a vital role in strengthening the relationship between board gender diversity [37]; hence, the interface between those two concepts is not doubtful. Moreover, there are scholars investigating the relationship between gender diversity and CSR. For instance, Orij et al. [38] assert that gender critical mass could moderate the firm's negative performance, one of the CSR indicators. Ugwuozor [39] researched students on the perception of CSR, and the obtained results showed that gender has a significant impact on the perception of CSR, i.e., female students are more sensitive to CSR. The results of another study, conducted in South Korea, showed that female consumers have a higher perception towards CSR than male consumers [40]. Lu et al. [41] investigated gender differences in corporate social responsibility implementation in Lithuania. They revealed that "female managers were more convinced to the benefits of CSR practices than their male counter-parts." Del Mar Alonso-Almeida [42] also stated that "social and environmental issues are more important to women." On the other hand, Calabrese et al. and Sobczak et al. [43,44] found out that there are no gender differences in the perception of CSR. The different results show that the perception of CSR is a sensitive issue, and there is no general approach to it, i.e., the perception of CSR, in terms of gender, should be examined on every market separately, as it could depend on historical and cultural variables of each particular country. Hence, the following hypothesis could be raised:

Hypothesis $1\left(\mathrm{H}_{1}\right)$. Gender has an influence on the perception of corporate social responsibility by employees.

Another aspect that is being examined by scholars is age's impact on attitude on CSR. For instance, Hommerová et al. [45] singled out that there is a correlation between age and perception of CSR. Vuković et al. [46] examined the perception of CSR in Serbia and used the socialist experience as a factor influencing the attitude toward CSR. The authors took age as an indicator of socialism and found out that socialist experience did not have an impact on perception; hence, it could be stated that age is not a critical factor in terms of CSR perception. On the other hand, the research done by Haski-Leventhal et al. [34] showed that the older age groups of students' attitude to CSR is more positive than the perception of the younger group. Wisse et al. [9] stressed the differences in CSR perception within different age groups because "CSR practices address those emotional needs and goals that are prioritised when people's future time perspective decreases." Rosati et al. [31] conducted research in Italy (the respondents were employees of Italian banks), and the results revealed that there is no significant difference between older and younger employees' perception of CSR. This brings contradictory results to the scientific literature, which means that age is a factor that is not researched enough. Moreover, the results could differ from country to country; consequentially, there is no one approach to the attitude toward CSR depending on age.

Hypothesis $2\left(\mathrm{H}_{2}\right)$. Age has an influence on the perception of corporate social responsibility by employees. 
To sum up, there are studies that investigate attitude toward CSR dependency on age and gender; however, there is a lack of researches examining the impact of the sector of employment on CSR perception. Actually, different sectors have different values; hence, the attitude toward CSR could vary from sector to sector. The sectors which require higher education in order to be employed are more likely to accept CSR than others. This statement is supported by the results received by several studies that were devoted to the investigation of education impact on CSR perception [43,47]. Melovic et al. [24] looked for the differences in CSR perception depending on employment in private and public sectors. Still, there are very few studies investigating the sector of employment impact on CSR perception [48]. Based on that, the following hypothesis is raised in the current research:

Hypothesis $3\left(\mathrm{H}_{3}\right)$. Sector of employment has an influence on the perception of corporate social responsibility by employees.

\section{Methodology}

The development of the research instrument was based on the CSR structure proposed by the World Business Council for Sustainable Development [49] and the structure of non-financial reporting, according to the Directive 2014/95/EU of the European Parliament and the Council of 22 October 2014. The Directive regarding the disclosure of non-financial and diversity information requires an obligatory inclusion of the information on "environmental, social and employee matters, respect for human rights, anti-corruption and bribery matters" [50]. The authors also used the statements from the questionnaire used within the survey, "Comparing the state of CSR in Baltics and Finland" [51].

The structure of the questionnaire (Part A: respondent profile) is reflected in Table 1. The structure of the questionnaire (Part B: general questions) is reflected in Table 2. Part B contains 35 statements, describing the company's CSR activities, divided into five groups.

Table 1. The structure of the questionnaire (Part A: Respondent profile).

\begin{tabular}{ccc}
\hline Label & Question & Type of the Question: Responses \\
\hline A_Q1 & Gender & Closed: 2 alternative responses (male; female) \\
\hline A_Q2 & Year of birth & $\begin{array}{c}\text { Closed: 4 alternative responses (1946-1964; } \\
\text { 1965-1980; 1981-2000; 2001 and later) }\end{array}$ \\
\hline A_Q3 & $\begin{array}{c}\text { Represented sector of the } \\
\text { economy }\end{array}$ & $\begin{array}{c}\text { Closed: 11 alternative responses } \\
\text { (main sectors + option "other") }\end{array}$ \\
\hline Source: developed by authors.
\end{tabular}

Source: developed by authors.

Table 2. The structure of the questionnaire (Part B: General questions).

\begin{tabular}{|c|c|c|}
\hline Code & Group of Statements & Labels of Statements \\
\hline B_Q1 & General attitude & \\
\hline B_Q2.1-2.4 & Strategic vision and transparency & $\begin{array}{l}\text { Strategy } \\
\text { Tax transparency } \\
\text { Code of ethics } \\
\text { Information provision }\end{array}$ \\
\hline B_Q2.5-2.9 & Honest business principles & $\begin{array}{l}\text { Salary } \\
\text { Taxes } \\
\text { Business honesty } \\
\text { Anti-corruption } \\
\text { Partners }\end{array}$ \\
\hline
\end{tabular}


Table 2. Cont.

\begin{tabular}{|c|c|c|}
\hline Code & Group of Statements & Labels of Statements \\
\hline B_Q2.10-2.16 & Customers and community & $\begin{array}{l}\text { Data security } \\
\text { Consumer interests } \\
\text { Customer claims } \\
\text { Sustainable consumption, } \\
\text { awareness-raising } \\
\text { Support to local community } \\
\text { Cooperation with NGO } \\
\text { Social programmes }\end{array}$ \\
\hline B_Q2.17-2.21 & Staff financial support & $\begin{array}{l}\text { Staff motivation system } \\
\text { Paid leaves } \\
\text { Medical insurance } \\
\text { Family support } \\
\text { Pension }\end{array}$ \\
\hline B_Q2.22-2.29 & Staff matters & $\begin{array}{l}\text { Flexible work } \\
\text { Equality } \\
\text { Work security and stress-reducing } \\
\text { Support staff relaxation } \\
\text { Team building } \\
\text { Staff training } \\
\text { Claims submission system } \\
\text { Job satisfaction assessment }\end{array}$ \\
\hline B_Q2.30-2.25 & Environment & $\begin{array}{l}\text { Resource-saving } \\
\text { Waste reduction } \\
\text { Waste management } \\
\text { Environment-friendly technologies } \\
\text { Environmental impact assessment } \\
\text { Environment-friendly processes }\end{array}$ \\
\hline
\end{tabular}

Source: developed by authors.

All the statements were offered to respondents for evaluation, using a 5-point scale, where " 1 " indicated "not important at all" whereas " 5 " means "extremely important."

One hundred twenty-nine respondents participated in the survey $(66 \%$ females, $34 \%$ males). Only representatives of generation $X$ (birth years 1965-1980) and generation Y (the birth years 1981-2000) were among the participants: $32 \%$ and $68 \%$, respectively. Most respondents were employed in the Education sector and the Construction sector (both sectors employed 19\% of respondents).

The quality of the measurement scale was tested within the framework of the authors' previously conducted research [14]. Cronbach alpha, for the whole scale, was equal to 0.966 , indicating an excellent overall consistency.

To test the research hypotheses, the authors applied regression analysis to identify the moderating effects of the control features in the sample (gender, age, and sector of the economy). To assess that two steps, regression analysis was performed with the sample by means of SPSS Statistics 25.0; the factor was estimated as a moderator in the case when, with direct regression analysis, it was a significant factor that appeared to become insignificant if another significant factor was added. To illustrate the achieved results, the authors also performed some graph analyses.

\section{Results}

Within the section below, we describe the key findings of the study. For each of the models described below, we had variance explained not less than 0.3 , so we only present results assuming we have the required quality of goodness. The necessary tests were performed to confirm the validity of the results, and only the valid results are presented below.

This study represents the additional results that were not presented by the authors in [14]; due to this, we focused on individual characteristics and overall CSR perception as 
key variables. To relate the findings to existing research, the authors perform a two-step moderation analysis, instead of sole linear regression, to test intermediary effects as well as direct ones.

For testing the first hypothesis, the role of gender in CSR perception, the authors implemented a two-step moderation analysis based on regression calculations. The results can be seen in Tables 3 and 4, accordingly. Business honesty was chosen as a predictor at the second stage of analysis, as regression analysis had indicated the significance of this factor.

Table 3. Assessment of gender as a moderating factor of CSR perception (step 1).

\begin{tabular}{cccccccc}
\hline \multirow{2}{*}{ Model } & \multicolumn{2}{c}{ Non-Standard Coefficients } & \multicolumn{2}{c}{$\begin{array}{c}\text { Standard } \\
\text { Coefficients }\end{array}$} & \multirow{2}{*}{$\mathbf{T}$} & Significance \\
\cline { 3 - 4 } & \multicolumn{2}{c}{$\mathbf{B}$} & Standard Error & Beta & & \\
\hline \multirow{2}{*}{1} & (Constant) & 4.705 & 0.207 & & 22.704 & $p<0.001$ \\
& Gender & -0.455 & 0.145 & -0.268 & & -3.126 & $p<0.01$ \\
\hline
\end{tabular}

Dependent variable: overall attitude.

Table 4. Assessment of gender as a moderating factor of CSR perception (step 2).

\begin{tabular}{|c|c|c|c|c|c|c|}
\hline & \multirow{2}{*}{ Model } & \multicolumn{2}{|c|}{ Non-Standard Coefficients } & \multirow{2}{*}{$\begin{array}{c}\begin{array}{c}\text { Standard } \\
\text { Coefficients }\end{array} \\
\text { Beta }\end{array}$} & \multirow{2}{*}{$\mathbf{T}$} & \multirow{2}{*}{ Significance } \\
\hline & & B & Standard Error & & & \\
\hline \multirow[b]{3}{*}{1} & (Constant) & 4.705 & 0.207 & & 22.704 & $p<0.001$ \\
\hline & Gender & -0.455 & 0.145 & -0.268 & -3.126 & $p<0.01$ \\
\hline & $\begin{array}{l}\text { Business } \\
\text { honesty }\end{array}$ & 0.306 & 0.076 & 0.330 & 4.029 & $p<0.001$ \\
\hline
\end{tabular}

Dependent variable: overall attitude.

As suggested by the two-step technique, the factor can be considered a moderator if its significance drops lower than the norm after adding another significant factor to the ANOVA model; this is the case seen in Tables 3 and 4; though, in a linear model where gender is considered an independent variable, the real role of this factor is moderating the relationship between the overall attitude of a person towards corporate social responsibility, whereas the key predicting independent variables are to be assessed by means of other tools. This fact can be illustrated by Figure 1, from which one can identify the difference between the male and female perceptions of CSR. As one can see, in general, female respondents are more likely to assess CSR as necessary, and the group is more solid in their perception compared to male peers.

The situation with generation's influence appeared to be different: the factor remains an independent variable on both steps of the two-step analysis, as one can derive from Tables 5 and 6 below.

Table 5. Assessment of generation as a moderating factor of CSR perception (step 1).

\begin{tabular}{|c|c|c|c|c|c|c|}
\hline & \multirow{2}{*}{ Model } & \multicolumn{2}{|c|}{ Non-Standard Coefficients } & \multirow{2}{*}{$\begin{array}{c}\begin{array}{c}\text { Standard } \\
\text { Coefficients }\end{array} \\
\text { Beta }\end{array}$} & \multirow[t]{2}{*}{$\mathbf{T}$} & \multirow[t]{2}{*}{ Significance } \\
\hline & & B & Standard Error & & & \\
\hline \multirow{2}{*}{1} & (Constant) & 4.852 & 0.252 & & 19.223 & $p<0.001$ \\
\hline & Generation & -0.449 & 0.144 & -0.268 & -3.122 & $p<0.01$ \\
\hline
\end{tabular}

Dependent variable: overall attitude. 
Table 6. Assessment of generation as a moderating factor of CSR perception (step 2).

\begin{tabular}{|c|c|c|c|c|c|c|}
\hline & \multirow{2}{*}{ Model } & \multicolumn{2}{|c|}{ Non-Standard Coefficients } & \multirow{2}{*}{$\begin{array}{c}\begin{array}{c}\text { Standard } \\
\text { Coefficients }\end{array} \\
\text { Beta }\end{array}$} & \multirow{2}{*}{$\mathbf{T}$} & \multirow{2}{*}{ Significance } \\
\hline & & B & Standard Error & & & \\
\hline \multirow[b]{3}{*}{1} & (Constant) & 3.376 & 0.399 & & 8.454 & $p<0.001$ \\
\hline & Generation & -0.453 & 0.134 & -0.270 & -3.386 & $p<0.01$ \\
\hline & $\begin{array}{l}\text { Business } \\
\text { honesty }\end{array}$ & 0.338 & 0.074 & 0.364 & 4.569 & $p<0.001$ \\
\hline
\end{tabular}

Dependent variable: overall attitude.

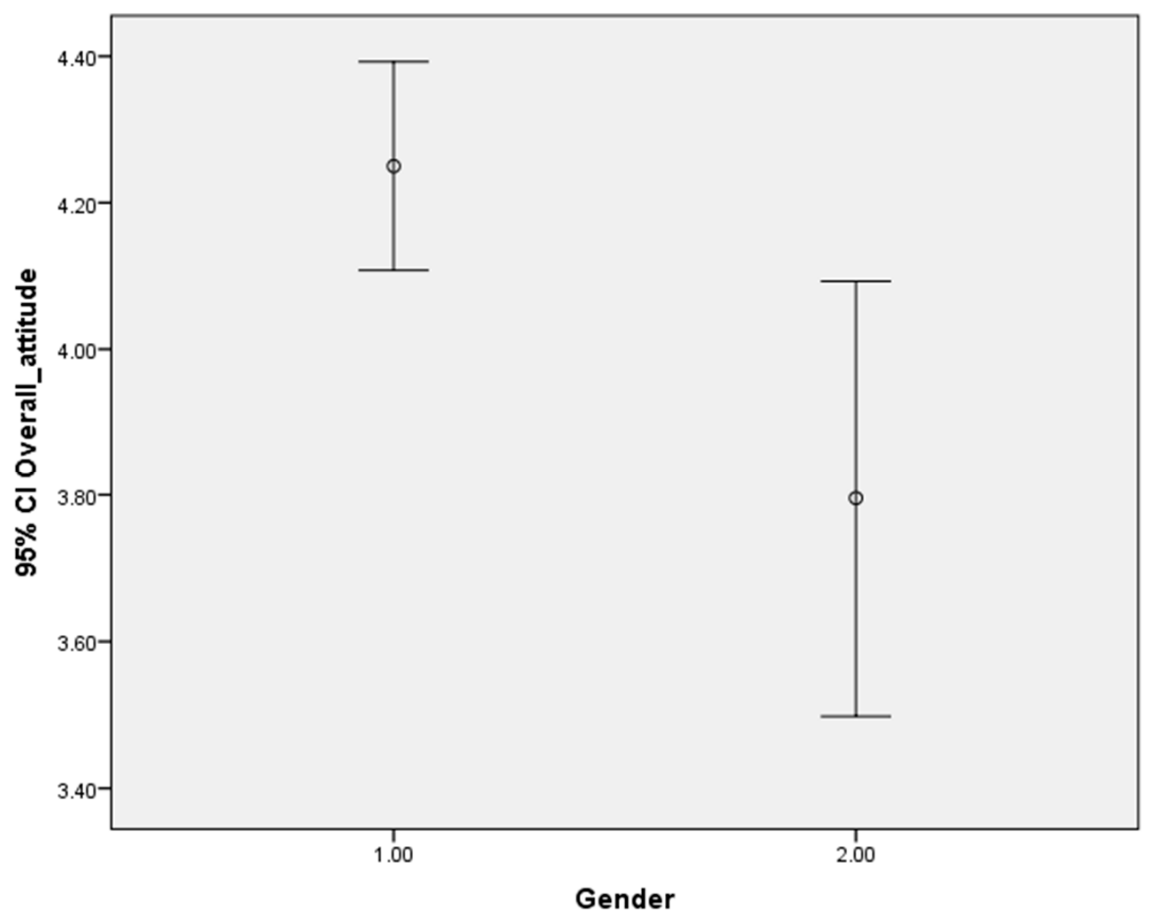

Figure 1. CSR perception error bar related to gender.

Generation can be assessed as a significant independent variable for assessment of CSR perception; the attitude changes in the following way-though somewhat unexpected, the younger generation (1981-2000 year of birth) assess corporate social responsibility as less important compared to the older generation. While for those born between 1965 and 1980 , the average importance of CSR is 4.35 on a 5-point scale, for the Y generation, it is a bit below 4 , so quite a few youngsters are not considering the issue.

Finally, we have assessed the role of the economic sector in relation to CSR perception (see Tables 7 and 8). With this hypothesis, the statistical analysis had not revealed any signs of the economic sector in personal perception of CSR - the factor remains insignificant on both stages of the two-step analysis. However, the model using business honesty assessment as a critical predictor is much more accurate.

Table 7. Assessment of an economic sector as a moderating factor of CSR perception (step 1).

\begin{tabular}{|c|c|c|c|c|c|c|}
\hline & \multirow{2}{*}{ Model } & \multicolumn{2}{|c|}{ Non-Standard Coefficients } & \multirow{2}{*}{$\begin{array}{c}\begin{array}{c}\text { Standard } \\
\text { Coefficients }\end{array} \\
\text { Beta } \\
\end{array}$} & \multirow[t]{2}{*}{$\mathrm{T}$} & \multirow{2}{*}{ Significance } \\
\hline & & B & Standard Error & & & \\
\hline \multirow[b]{2}{*}{1} & (Constant) & 3.844 & 0.142 & & 27.002 & $p<0.001$ \\
\hline & $\begin{array}{l}\text { Economic } \\
\text { sector }\end{array}$ & 0.041 & 0.020 & 0.177 & 2.018 & $p<0.05$ \\
\hline
\end{tabular}

Dependent variable: overall attitude. 
Table 8. Assessment of an economic sector as a moderating factor of CSR perception (step 2).

\begin{tabular}{|c|c|c|c|c|c|c|}
\hline & \multirow{2}{*}{ Model } & \multicolumn{2}{|c|}{ Non-Standard Coefficients } & \multirow{2}{*}{$\begin{array}{c}\begin{array}{c}\text { Standard } \\
\text { Coefficients }\end{array} \\
\text { Beta }\end{array}$} & \multirow{2}{*}{$\mathbf{T}$} & \multirow{2}{*}{ Significance } \\
\hline & & B & Standard Error & & & \\
\hline \multirow{3}{*}{1} & (Constant) & 2.247 & 0.366 & & 6.137 & $p<0.001$ \\
\hline & $\begin{array}{c}\text { Economic } \\
\text { sector }\end{array}$ & 0.048 & 0.019 & 0.210 & 2.577 & $p<0.05$ \\
\hline & $\begin{array}{l}\text { Business } \\
\text { honesty }\end{array}$ & 0.354 & 0.076 & 0.381 & 4.675 & $p<0.001$ \\
\hline
\end{tabular}

Dependent variable: overall attitude.

The graph analysis (see Figure 2) indicates that the only industry where the perception of CSR is solid is transport and warehousing (i.e., logistics). In contrast, in all other cases, one case sees a high variation of the results.

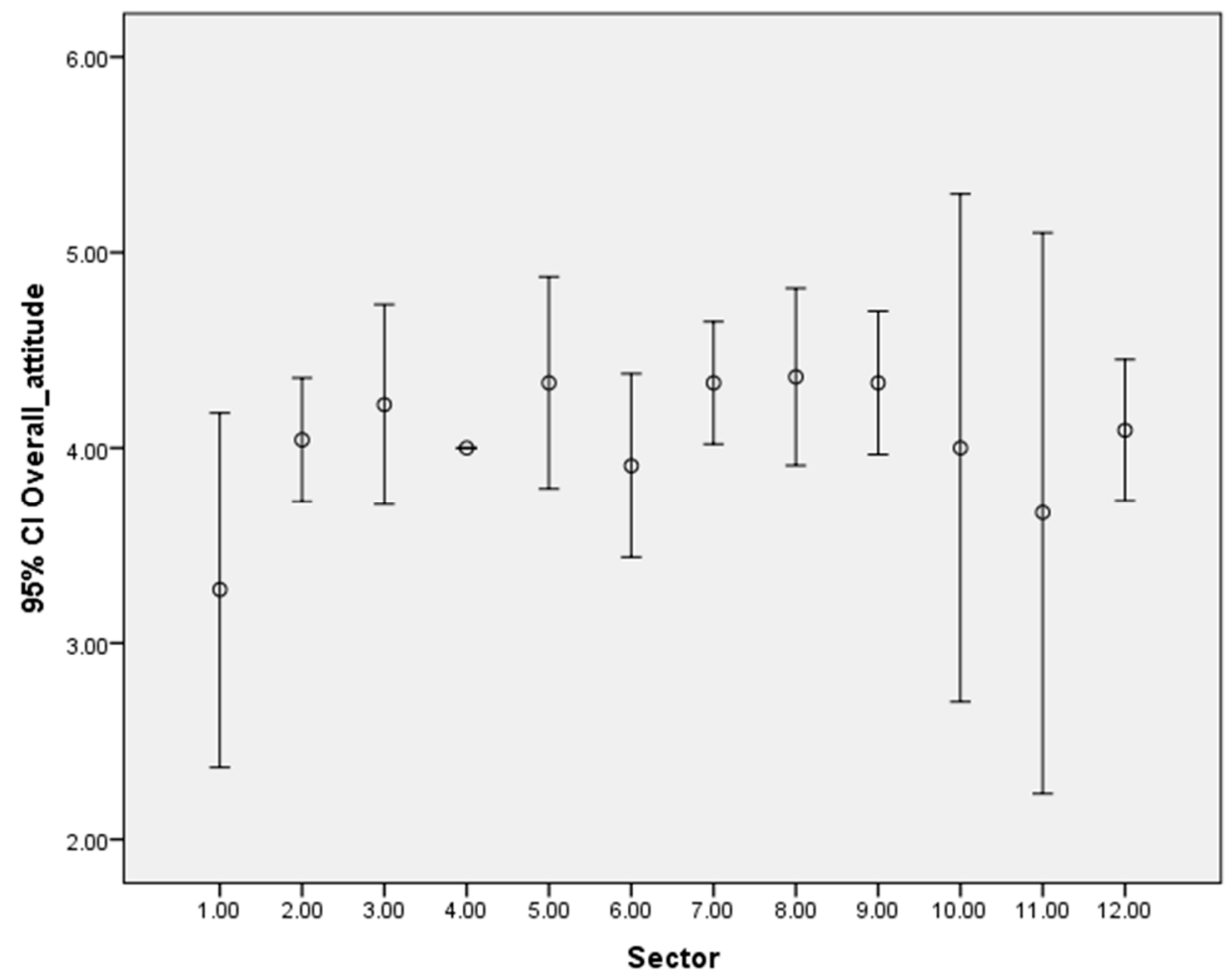

Figure 2. CSR perception error bar related to economic sector.

\section{Discussion}

Summarising the research above, we can state the following in relation to the hypothesis stated in the introductory part of the paper.

The aspect of gender, in terms of CSR, is discussed in the scientific literature; however, the researchers still remain fragmented. First, we needed to check the role of gender, stated as Hypothesis 1: gender has an influence on the perception of corporate social responsibility by employees. This hypothesis was supported throughout the whole sample. Next, we were to assess the influence of age (generation) on the personal perception of CSR, which formed Hypothesis 2: age has an influence on the perception of corporate social responsibility by employees. This hypothesis was partly supported-age appeared to be an independent variable but not a moderator. To sum up, we came with hypothesis 3 : sector of employment has an influence on the perception of corporate social responsibility by employees. This hypothesis was unsupported (with an exception to the logistics sector). 
The findings presented in the section above create some room for discussion in terms of how they correlate with the existing literature. First, hypothesis 1 was fully supported, indicating gender is a factor that influences personal CSR perception. Thus, our research contradicts the findings of Calabrese et al. [44] and Sobczak et al. [43], who have found no gender gaps in their research; on the opposite end, our research supports the findings of García-Sánchez et al. [35] and Nwude and Nwude [36] who claim females to be more perceptive to the CSR practices compared to males. Our research had indicated that female CSR perception is significantly higher than males. Thus, for the existing sample of European $X$ and $Y$ generation representatives, our findings confirm the existence of gender bias in CSR perception, as major literature indicates.

Our research confirmed that one could see the generation bias in personal CSR perception, which is in line with existing literature (for instance, Haski-Leventhal et al. [34] and Rosati et al. [31] had found the same tendency worldwide and in Italy, accordingly). The same was true for our sample; on the other hand, our research had gone a bit further to evaluate the moderating role of age in CSR perception, but this part of our hypothesis 2 was not supported. Age is a factor that influences CSR perception directly, as suggested by other researchers, but we did not find support for our suggestion that age can also be a moderating factor.

Finally, we revealed that only the logistics industry has an impact on personal CSR perception, while in the other sectors, one can see very controversial CSR perception (defined by age and gender). While Cambra-Fierro et al. [47], along with Sobczak et al. [43], indicated the influence of the education field on CSR (and this one influences the employment sector), we have not found support for this suggestion. The industry influenced CSR perception not directly, neither as a moderator-with a sole exception of the logistics industry. Thus, our results contradict existing findings, yet the latter is quite rare, so this area requires additional research.

\section{Conclusions}

The given paper examines the differences in attitude towards corporate social responsibility among the respondents of different ages, gender, and represented sectors of employment. The findings in the paper support existing literature in terms of moderating the role of gender, as outlined previously by Rosati et al. [31]; yet, this research estimated that males value corporate social responsibility higher than females, while our results estimate the opposite. Second, our study had revealed that age (generation) is a significant factor that defines a personal attitude towards corporate social responsibility. This was found by Haski-Leventhal et al. [34], but we also have opposite results since the older generation values CSR higher than the youngsters. Third, opposite of Sobczak et al. [43], we have not found any correlation between the economic sector and corporate social responsibility perception.

Thus, the stated hypotheses are validated as follows:

1. $\mathrm{H}_{1}$ is fully supported. Gender is a factor that influences personal CSR perception, and this factor is moderating the attitude towards different aspects of CSR onto the overall estimation of its importance.

2. $\mathrm{H}_{2}$ is partly supported. Generation is a factor that influences personal CSR perception, but this factor is independent and does not act as a moderator between individual characteristics and the overall estimation of CSR importance.

3. $\mathrm{H}_{3}$ was unsupported. The economic sector is neither an independent predictor nor moderator for CSR perception on an individual level (with an exception for the logistics-related industry).

These results correlate with the controversial findings on CSR perception revealed in the existing literature and are in line with the idea of CSR being a complex phenomenon that should be studied in more detail. 
The paper contributes to the literature in the field of CSR-related issues with its specific national context, a comprehensive research instrument, and sector-related aspect of CSR perception.

The current study has a number of limitations which could lead to potential bias. First, the sample included 129 valid responses which is enough to draw conclusions and yet is relatively small. Second, the sample was somewhat biased towards educational and construction sectors, which could again influence the achieved results.

Taking into account the limited sample size, the current study has a potential for continuation, increasing the number of respondents or expanding the geographical areafor instance, covering all Baltic States. The developed questionnaire could be used to conduct in-depth research within specific economic sectors.

Author Contributions: Conceptualisation, J.T., T.T., A.S. and V.S.; methodology, J.T., T.T., A.S. and V.S.; software, J.T., T.T., A.S. and V.S.; validation, J.T. and T.T.; formal analysis, J.T., T.T., A.S. and V.S.; investigation, J.T., T.T.; resources, J.T., T.T., A.S. and V.S.; data curation, J.T., T.T., A.S. and V.S.; writing—original draft preparation, J.T., T.T., A.S. and V.S.; writing—review and editing, J.T., T.T., A.S. and V.S.; visualisation, A.S.; supervision, J.T. All authors have read and agreed to the published version of the manuscript.

Funding: This research received no external funding.

Institutional Review Board Statement: Not applicable.

Informed Consent Statement: Not applicable.

Data Availability Statement: The data was gathered by conducting a survey in Latvia.

Conflicts of Interest: The authors declare no conflict of interest.

\section{References}

1. Stubbs, W.; Schapper, J. Two approaches to curriculum development for educating for sustainability and CSR. Int. J. Sustain. High. Educ. 2011, 12, 259-268. [CrossRef]

2. Usman, B. CSR Performance Firm's Attributes, and Sustainability Reporting. Int. J. Bus. Soc. 2020, 21, 521-539. [CrossRef]

3. Nguyen, H.T.; Le, D.M.D.; Ho, T.T.M.; Nguyen, P.M. Enhancing sustainability in the contemporary model of CSR: A case of fast fashion industry in developing countries. Soc. Responsib. J. 2020, 17, 578-591. [CrossRef]

4. Schnepp, G.J.; Bowen, H.R. Social Responsibilities of the Businessman. Am. Cathol. Sociol. Rev. 1954, 15, 42. [CrossRef]

5. Maqbool, S.; Zameer, M.N. Corporate social responsibility and financial performance: An empirical analysis of Indian banks. Futur. Bus. J. 2018, 4, 84-93. [CrossRef]

6. Aramburu, I.A.; Pescador, I.G. The Effects of Corporate Social Responsibility on Customer Loyalty: The Mediating Effect of Reputation in Cooperative Banks Versus Commercial Banks in the Basque Country. J. Bus. Ethics 2017, 154, 701-719. [CrossRef]

7. Chang, Y.-H.; Yeh, C.-H. Corporate social responsibility and customer loyalty in intercity bus services. Transp. Policy 2017, 59, 38-45. [CrossRef]

8. Maruf, A.A. Corporate Social Responsibility and Corporate Image. Transnatl. J. Sci. Technol. 2013, 3, $29-49$.

9. Wisse, B.; Van Eijbergen, R.; Rietzschel, E.F.; Scheibe, S. Catering to the Needs of an Aging Workforce: The Role of Employee Age in the Relationship Between Corporate Social Responsibility and Employee Satisfaction. J. Bus. Ethics 2015, 147, 875-888. [CrossRef]

10. Tambovceva, T.; Titko, J.; Alksne, A. Corporate Social Responsibility Perceived by Latvian Enterprises. In Proceedings of the 30th International Business Information Management Association Conference, IBIMA 2017-Vision 2020: Sustainable Economic Development, Innovation Management, and Global Growth, Madrid, Spain, 8-9 November 2017; pp. 1557-1568.

11. Verina, N.; Titko, J.; Lejniece, I. Tax Governance as a Part of Corporate Social Responsibility. In Proceedings of the 10th International Scientific Conference „Business and Management 2018“, Vilnius, Lithuania, 3-4 May 2018. [CrossRef]

12. Vēvere, V.; Linina, I. Ethical Leadership: Meaning and Measurement. Latvian Retail Traders' Perspective. Econ. Cult. 2016, 13, 89-96. [CrossRef]

13. Brante, I.; Lejniece, I.; Lejnieks, H. Reliability and Reputation of the Board Member in Latvia. Econ. Cult. 2020, 17, 140-149. [CrossRef]

14. Titko, J.; Skvarciany, V.; Tambovceva, T. Corporate Social Responsibility Perceived by Employees: Latvian Survey Results. Central Eur. Bus. Rev. 2021, 10, 37-50. [CrossRef]

15. Asemah, E.S.; Okpanachi, R.A.; Edegoh, L.O.N. Business Advantages of Corporate Social Responsibility Practice: A Critical Review. New Media Mass Commun. 2013, 18, 45-54. [CrossRef]

16. Księżak, P. The Benefits from CSR for a Company and Society. J. Corp. Responsib. Leadersh. 2017, 3, 53-65. [CrossRef] 
17. Brammer, S.; Millington, A.; Rayton, B. The contribution of corporate social responsibility to organizational commitment. Int. J. Hum. Resour. Manag. 2007, 18, 1701-1719. [CrossRef]

18. Galbreath, J. How does corporate social responsibility benefit firms? Evidence from Australia. Eur. Bus. Rev. 2010, 22, 411-431. [CrossRef]

19. Lee, L.; Chen, L.-F. Boosting employee retention through CSR: A configurational analysis. Corp. Soc. Responsib. Environ. Manag. 2018, 25, 948-960. [CrossRef]

20. Thuy, C.T.M.; Khuong, N.V.; Canh, N.T.; Liem, N.T. Corporate Social Responsibility Disclosure and Financial Performance: The Mediating Role of Financial Statement Comparability. Sustainability 2021, 13, 10077. [CrossRef]

21. Devie, D.; Liman, L.P.; Tarigan, J.; Jie, F. Corporate social responsibility, financial performance and risk in Indonesian natural resources industry. Soc. Responsib. J. 2018, 16, 73-90. [CrossRef]

22. Saeidi, S.P.; Sofian, S.; Saeidi, P.; Saeidi, S.P.; Saaeidi, S.A. How does corporate social responsibility contribute to firm financial performance? The mediating role of competitive advantage, reputation, and customer satisfaction. J. Bus. Res. 2015, 68, 341-350. [CrossRef]

23. Xie, X.; Jia, Y.; Meng, X.; Li, C. Corporate social responsibility, customer satisfaction, and financial performance: The moderating effect of the institutional environment in two transition economies. J. Clean. Prod. 2017, 150, 26-39. [CrossRef]

24. Melovic, B.; Milovic, N.; Backovic-Vulic, T.; Dudic, B.; Bajzik, P. Attitudes and Perceptions of Employees toward Corporate Social Responsibility in Western Balkan Countries: Importance and Relevance for Sustainable Development. Sustainability 2019, 11, 6763. [CrossRef]

25. Nedelko, Z.; Potocan, V. Perception of Corporate Social Responsibility by the Employees. In Empowering Organizations through Corporate Social Responsibility; IGI Global: Hershey, PA, USA, 2015; pp. 51-72. [CrossRef]

26. Collier, J.; Esteban, R. Corporate social responsibility and employee commitment. Bus. Ethics A Eur. Rev. 2007, 16, 19-33. [CrossRef]

27. Paruzel, A.; Klug, H.J.P.; Maier, G.W. The Relationship between Perceived Corporate Social Responsibility and Employee-Related Outcomes: A Meta-Analysis. Front. Psychol. 2021, 12, 607108. [CrossRef]

28. Gharleghi, B.; Jahanshahi, A.A.; Nawaser, K. The Outcomes of Corporate Social Responsibility to Employees: Empirical Evidence from a Developing Country. Sustainability 2018, 10, 698. [CrossRef]

29. Yan, A.; Tang, L.; Hao, Y. Can Corporate Social Responsibility Promote Employees' Taking Charge? The Mediating Role of Thriving at Work and the Moderating Role of Task Significance. Front. Psychol. 2021, 11, 4072. [CrossRef]

30. Becton, J.B.; Walker, H.J.; Jones-Farmer, A. Generational differences in workplace behavior. J. Appl. Soc. Psychol. 2014, 44, 175-189. [CrossRef]

31. Rosati, F.; Costa, R.; Calabrese, A.; Pedersen, E.R.G. Employee attitudes towards corporate social responsibility: A study on gender, age and educational level differences. Corp. Soc. Responsib. Environ. Manag. 2018, 25, 1306-1319. [CrossRef]

32. Ahmad, N.; Ullah, Z.; Arshad, M.Z.; Kamran, H.W.; Scholz, M.; Han, H. Relationship between corporate social responsibility at the micro-level and environmental performance: The mediating role of employee pro-environmental behavior and the moderating role of gender. Sustain. Prod. Consum. 2021, 27, 1138-1148. [CrossRef]

33. Rank, S.; Contreras, F. Do Millennials pay attention to Corporate Social Responsibility in comparison to previous generations? Are they motivated to lead in times of transformation? A qualitative review of generations, CSR and work motivation. Int. J. Corp. Soc. Responsib. 2021, 6, 1-13. [CrossRef]

34. Haski-Leventhal, D.; Pournader, M.; McKinnon, A. The Role of Gender and Age in Business Students' Values, CSR Attitudes, and Responsible Management Education: Learnings from the PRME International Survey. J. Bus. Ethics 2015, 146, 219-239. [CrossRef]

35. García-Sánchez, I.-M.; Rodríguez-Ariza, L.; Granada-Abarzuza, M.-D. The Influence of Female Directors and Institutional Pressures on Corporate Social Responsibility in Family Firms in Latin America. J. Risk Financ. Manag. 2021, 14, 28. [CrossRef]

36. Nwude, E.C.; Nwude, C.A. Board Structure and Corporate Social Responsibility: Evidence From Developing Economy. SAGE Open 2021, 11, 2158244020988543. [CrossRef]

37. Saleh, M.W.; Zaid, M.A.; Shurafa, R.; Maigoshi, Z.S.; Mansour, M.; Zaid, A. Does board gender enhance Palestinian firm performance? The moderating role of corporate social responsibility. Corp. Gov. Int. J. Bus. Soc. 2021. [CrossRef]

38. Orij, R.P.; Rehman, S.; Khan, H.; Khan, F. Is CSR the new competitive environment for CEOs ? The association between CEO turnover, corporate social responsibility and board gender diversity: Asian evidence. Corp. Soc. Responsib. Environ. Manag. 2021, 28, 731-747. [CrossRef]

39. Ugwuozor, F.O. Students' perception of corporate social responsibility: Analyzing the influence of gender, academic status, and exposure to business ethics education. Bus. Ethics A Eur. Rev. 2020, 29, 737-747. [CrossRef]

40. Hur, W.-M.; Kim, H.; Jang, J.H. The Role of Gender Differences in the Impact of CSR Perceptions on Corporate Marketing Outcomes. Corp. Soc. Responsib. Environ. Manag. 2015, 23, 345-357. [CrossRef]

41. Lu, J.; Ren, L.; Zhang, C.; Wang, C.; Petkeviciute, N.; Streimikis, J. Gender difference in corporate social responsibility implementation in Lithuanian SMEs. Oeconomia Copernic. 2020, 11, 549-569. [CrossRef]

42. Alonso-Almeida, M.D.M.; Perramon, J.; Bagur, L. Women managers and corporate social responsibility (CSR) in Spain: Perceptions and drivers. Women's Stud. Int. Forum 2015, 50, 47-56. [CrossRef]

43. Sobczak, A.; Debucquet, G.; Havard, C. The impact of higher education on students' and young managers' perception of companies and CSR: An exploratory analysis. Corp. Gov. Int. J. Bus. Soc. 2006, 6, 463-474. [CrossRef] 
44. Calabrese, A.; Costa, R.; Rosati, F. Gender differences in customer expectations and perceptions of corporate social responsibility. J. Clean. Prod. 2016, 116, 135-149. [CrossRef]

45. Hommerová, D.; Šrédl, K.; Vrbková, L.; Svoboda, R. The Perception of CSR Activities in a Selected Segment of McDonald's Customers in the Czech Republic and Its Effect on Their Purchasing Behavior-A Case Study. Sustainability 2020, $12,8627$. [CrossRef]

46. Vuković, A.; Miletić, L.; Ćurčić, R.; Ničić, M.; Mitrović, N. Employees' Perception of CSR in a Specific Post-Socialist Context: The Case of Serbia. J. East Eur. Manag. Stud. 2020, 25, 55-83. [CrossRef]

47. Cambra-Fierro, J.J.; Flores-Hernández, J.A.; Pérez, L.; Valera-Blanes, G. CSR and branding in emerging economies: The effect of incomes and education. Corp. Soc. Responsib. Environ. Manag. 2020, 27, 2765-2776. [CrossRef]

48. Vveinhardt, J.; Sroka, W. Workplace Mobbing in Polish and Lithuanian Organisations with Regard to Corporate Social Responsibility. Int. J. Environ. Res. Public Health 2020, 17, 2944. [CrossRef] [PubMed]

49. Hohnen, P.; Potts, J. Corporate Social Responsibility: An Implementation Guide for Business; International Institute for Sustainable Development: Winnipeg, MB, Canada, 2007.

50. European Parliament. Directive 2014/95/EU of the European Parliament and of the Council—of 22 October 2014-Amending Directive 2013/34/EU as Regards Disclosure of Non-Financial and Diversity Information by Certain Large Undertakings and Groups; European Parliament: Brussels, Belgium, 2014.

51. Alijošiutè, A. Comparing State of CSR in Baltic States and Finland. 2015. Available online: https://bit.ly/2YHdlTi (accessed on 28 June 2020). 